\title{
Table of Contents / Содержание
}

Table of Contents / Содержание . . . . . . . . . . . . . . . . . . . . . vii

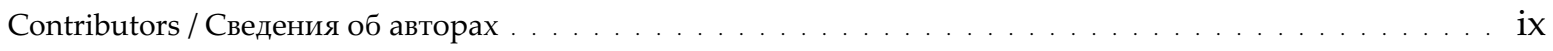

Note for Contributors / Будущим авторам . . . . . . . . . . . . . . . . . . X

\section{Issue 3 / Часть 3}

\section{Articles / Статьи}

Thiago Costa Chacon, Johann-Mattis List. Improved computational models of sound change shed light on the history of the Tukanoan languages

[T. К. Шакон, Й.-М. Аист. Уточнение компьютерной модели звуковых изменений помогает понять историю языков тукано]

И. А. Грунтов, О. М. Мазо. Классификация монгольских языков

по лексикостатистическим данным

[Ilya Gruntov, Olga Mazo. Lexicostatistical classification of the Mongolic languages]

Tatyana A. Mikhailova. Celtic origin: location in time and space?

Reconsidering the "East-West Celtic" debate

[T. А. Михайлова. Происхождение кельтов: время и место? По поводу развернувшейся дискуссии о центральноевропейском или же атлантическом сценарии]

\section{Reports / Хроника}

The precursors of Proto-Indo-European: The Indo-Hittite and Indo-Uralic hypotheses, Пейден, Leiden University, 9-11 июля 2015 г. (М. А. Живлов, Н. Ю. Живлова)

\section{Issue 4 / Часть 4}

\section{Articles / Статьи}

Sergei L. Nikolaev. Toward the reconstruction of Proto-Algonquian-Wakashan.

Part 2: Algonquian-Wakashan sound correspondences

[C. А. Николаев. К реконструкции алгонкино-вакашского праязыка. Ч. 2: Алгонкино-вакашские звуковые соответствия]

Miguel Valério. Linear A du-puz-re, Hittite tabarna and their alleged relatives revisited

[Мигель Валерио. Аинейное А du-puz-re, хеттское tabarna и их гипотетические когнаты]

А. И. Коган. Дардские языки и пятидесятисловная лексикостатистика 
М. Н. Саенко. История далматинского и балкано-романских языков с точки зрения лексикостатистики . . . . . . . . . . . . . . . . . . . . . . . . . . . . 371 [Mikhail Saenko. History of the Dalmatian and Balkan Romance languages from the lexicostatistical point of view]

\section{Book Reviews / Рецензии}

William H. BAXTER, Laurent SAGART. Old Chinese. A New Reconstruction, 2014

(George Starostin / Г. C. Сmapocmuн)

Ranko MATASOVIĆ. Slavic Nominal Word-Formation. Proto-Indo-European Origins and Historical Development, 2014 (Ж. Ж. Варбот / Zh. Zh. Varbot) 